\title{
Adverbial Morphology: How Dutch and German are Moving Away from English
}

\author{
Janneke Diepeveen \\ Freie Universität Berlin \\ Freek Van de Velde \\ University of Leuven
}

\begin{abstract}
English marks the distinction between adjectives and adverbs with an adverbial suffix, whereas Dutch and German allow adjectives to be used adverbially without extra morphology. This may give rise to the idea that English, like Latin, is more specific in its classification of various types of modifiers. We propose an alternative analysis: Dutch and German draw a different dividing line, between attributive modifiers (NP-level) on the one hand, and predicative and adverbial modifiers (clause-level) on the other. To this end, they use adjectival inflection instead of derivational morphology. We describe how the adverbial systems in these three West-Germanic languages have developed and try to explain the changes that have occurred.
\end{abstract}

\section{Introduction.}

In the present article, three main points are addressed. First, we argue that the classical idea that Dutch and German, as opposed to English, lump adjectives and adverbs together in one part-of-speech category is an inaccurate description of the present-day situation. Dutch and German just make a different split in the part-of-speech system: Rather than distinguishing between adjectives and adverbs, they draw a dividing line between NP-modifiers and clause-level modifiers. Several arguments are given in support of this view.

Second, we take a closer look at the diachrony of the adverbial system in the three languages in order to assess when and why English on the one hand and Dutch and German on the other hand have gone separate ways.

Third, we provide an overview of some current developments in the adverbial morphology in Dutch and German, to show that the changes

(C) Society for Germanic Linguistics 
that have resulted in the split between the latter two languages and English have not yet come to a halt.

\section{Present-Day Situation.}

As illustrated in 1a,b Dutch and German use adjectives as adverbials without adding any morphological marking. As a result, there is a formal overlap with predicative adjectives as in $2 \mathrm{a}, \mathrm{b}$, which are also uninflected.

(1) a. Present-day Dutch

Hij praat vreemd.

he speaks strange

'He speaks strangely.'

b. Present-day German

Er spricht seltsam.

he speaks strange

'He speaks strangely.'

(2) a. Present-day Dutch

Hij is vreemd.

he is strange

'He is strange.'

b. Present-day German

Er ist seltsam.

he is strange

'He is strange.'

English, by contrast, makes a formal distinction between adverbial and adjectival modifiers. It systematically and productively uses the suffix -ly to mark adverbials. ${ }^{1}$ As such, the English adverbial system is a

${ }^{1}$ There are only a handful of exceptions. A fixed number of adjectives are not suffixed with $-l y$, such as hard (note the meaning difference with hardly) and fast. For adjectives ending in -ly, adverbial suffixing is avoided, as in *friendlily; suffixing is not possible for time modifiers such as weekly and daily. In informal spoken English, -ly may be left out. Nevalainen (1997:183) provides arguments for the "demise of zero-derivation as a regular process of adverbialization in 
traditional one, that is, one that fits with the traditional Latin-based grammar. One could state then that Dutch and German are less specific in their part-of-speech distinctions.

However, if we free ourselves from the traditional part-of-speech classification, it becomes clear that Dutch and German are in fact as specific as English, but that they have developed an entirely different formal strategy. The demarcation line is not between adjectives and adverbs, but rather between NP-modifiers (attributive adjectives) on the one hand and clause-level modifiers (predicative adjectives and adverbs) on the other. Contrary to English, they do not mark the difference by means of a derivational suffix (-ly) but use inflection instead: attributive adjectives are inflected, whereas clause-level modifiers are not. This is summarized in table $1 .^{2}$

\begin{tabular}{|l|l|l|l|}
\hline & Attributive use & Predicative use & Adverbial use \\
\hline English & Adjective & adjective $+-l y$ \\
\hline $\begin{array}{l}\text { Dutch, } \\
\text { German }\end{array}$ & $\begin{array}{l}\text { adjective }+ \\
\text { inflection }\end{array}$ & uninflected adjective \\
\hline
\end{tabular}

Table 1. Modifier systems in English, Dutch, and German. ${ }^{3}$

In Dutch and German, adjectives are only inflected in prenominal attributive position. In Dutch, the adjective is inflected by default, as shown in 3a. Apart from some minor exceptions (see Haeseryn et al.

Standard English" and the regularization of adverbial -ly. Because of its systematicity, there is some discussion whether adverbial -ly is inflectional rather than derivational (see, among others, Brinton \& Traugott 2005:134ff).

${ }^{2}$ See also Paraschkewoff (1974:290) for a diachronic variant of this table for the situation in German.

${ }^{3}$ With table 1 we do not intend to make universal claims on what divisions are possible cross-linguistically. That is, we do not want to deny that languages other than English, Dutch, and German lump all categories together, or that they have a three-way distinction. Note, however, that non-verbal encoding of predicative adjectives is cross-linguistically not the only option. As Stassen (2008) argues, it is an areal phenomenon, with Europe as one of the clusters. A not uncommon alternative strategy is to encode those predicates in a verbal way. 
1997:400-401,405-412), the ending is only missing with neuter singular nouns preceded by an indefinite determiner, as in $3 \mathrm{~b}$.

(3) Present-day Dutch (38MWC) ${ }^{4}$

a. een mooi-e tekening

a nice-INFL drawing

'a nice drawing'

b. een mooi boek

a nice book

'a nice book'

German adjectives inflect for gender, number, and case in prenominal attributive position. All inflectable adjectives can be inflected according to two paradigms: the strong and the weak inflection. ${ }^{5}$ The syntactic context determines which inflection applies (see König \& Gast 2007:65-66), as shown in 4.

(4) Present-day German (DWDS) ${ }^{6}$

a. ein schön-es Bild

a nice-INFL picture

'a nice picture'

b. das schön-e Buch

the nice-INFL book

'the nice book'

It seems then that an insightful generalization for both Dutch and German is that the adjective inflects only in attributive use (compare predicative examples in 2).

\footnotetext{
${ }^{4} 38$ Million Words Corpus: see Kruyt \& Dutilh 1997 for details.

${ }^{5}$ There is a third, mixed type of paradigm (see König \& Gast 2007:66) and a small group of uninflectable adjectives in German, for example, prima 'excellent' and super 'marvellous'.

${ }^{6}$ DWDS: Das Digitale Wörterbuch der deutschen Sprache des 20. Jh., Kerncorpus.
} 
Apart from the morphological split between the inflected attributive modifier, and the uninflected predicative and adverbial modifier, there are three additional arguments that support the classification proposed in table 1: (i) accretion of inflected forms inside the NP, (ii) lexical restrictions, and (iii) prosodic differences.

By accretion of inflected forms inside the NP we mean the tendency to make the distinction between NP-level modifiers and clause-level modifiers more consistent through time. This can be illustrated by two phenomena: PROLEPTIC INFLECTION and ANALOGICAL LEVELING of the inflected form.

Proleptic inflection is the term used by Royen (1948:83-92) for inflection on degree adverbs when they modify an attributive adjective. Normally, these degree adverbs remain uninflected, just like other adverbs, but in cases of proleptic inflection they "copy" as it were the adjectival inflection. So instead of the regular pattern in 5a, with the uninflected degree adverb heel, Dutch also allows 5b. Indeed, in the $38 \mathrm{MWC}$ corpus, the proleptic-inflection string hele mooie clearly outnumbers the "regular" string heel mooie with $60 \%$ to $40 \%(n=67){ }^{7}$

(5) Present-day Dutch (38MWC)

a. een heel mooi-e periode a very nice-INFL period 'a very nice period'

b. een hel-e mooi-e periode a very-INFL nice-INFL period 'a very nice period'

It is not clear when exactly proleptic inflection first arose, but Royen's (1948) first examples date from the Modern Dutch period. Proleptic inflection currently does not only occur with the degree adverb heel, but with other degree adverbials as well, such as erg 'very', echt 'really',

\footnotetext{
${ }^{7}$ Given that proleptic inflection is generally considered to be characteristic for informal spoken Dutch (see, among others, Haeseryn et al. 1997:452), the proportion is probably even more skewed in spoken Dutch. This is supported by Google counts in Weerman 2005.
} 
geweldig 'tremendously', ontzettend 'awfully', vreselijk 'terribly' (see Royen 1948:92). ${ }^{8}$

The second phenomenon illustrating what we refer to as accretion of inflected forms inside NPs is analogical leveling of the inflected form. As Weerman (2003) points out, the Dutch inflectional ending seems to be extended to indefinite singular neuter noun phrases such as in $6 .{ }^{9}$ The only exception to the general rule, namely, that attributive adjectives have a zero inflection in singular neuter indefinite NPs, is dropped. The effect is that the formal distinction between (inflected) prenominal attributes and (uninflected) other modifiers is being systematized in Dutch.

(6) (Ethnic) present-day Dutch

een mooi-e verhaal

a nice-INFL story

'a nice story'

The second additional argument for the German and Dutch system in table 1 comes from lexical restrictions on the various uses of modification. Some modifiers, such as Dutch anders and gisteren, cannot be used as attributive adjectives, and in dictionaries and reference grammars they are generally treated as adverbs. To be sure, historically both words show adverbial morphology. Yet, upon closer inspection they can be used as predicates as well, as in 7a, which they should not if predicates are adjectives, as in $7 \mathrm{~b}, \mathrm{c} .^{10}$

\footnotetext{
${ }^{8}$ According to Royen (1948:83), the phenomenon is also attested in German dialects, but it is not attested in standard German.

${ }^{9}$ This development may be connected with a generalization of common gender (using de for neuter words) as Dutch speakers' intuition for gender is diminishing. This automatically entails generalization of the inflectional ending $-e$. Still, as Weerman et al. (2006) have shown, the extension of the $e$-inflection cannot be fully reduced to the loss of gender.

${ }^{10}$ The situation is complicated by the fact that in Dutch and German, adverbs can be used to modify a noun. However, this requires a special morphosyntactic operation in both languages. In Dutch, the adverb has to be used postnominally, see (i). It is no coincidence that adjectives in postnominal position have predicative characteristics (Haeseryn et al. 1997:865-866, Van de Velde 2009: 83-85). In German, the adverbs can be used prenominally, as in (ii), but note
} 
(7) Present-day Dutch

a. Hij is ander-s dan zijn vader he is other-ADV than his father 'He is different from his father'

b. Maar dit onafhankelijke advies.bureau but this independent consultancy.office

werkt ander-s

works other-ADV

'But this independent consultancy works differently'

c. een ander/*ander-s kind

a other/other-ADV child 'another child'

The third additional argument for the NP/clause split is seen in prosodic differences in a certain class of morphologically complex adjectives in Dutch. They are referred to in the literature as SYNTHETIC COMPOUNDS (see Booij 2002:158-161 for details). These adjectives display variation in their stress pattern: words such as meerledig 'multifaceted' can either be pronounced with the word stress on the first syllable or on the second syllable. The variation is syntactically constrained to some extent. In attributive position, both stress patterns are allowed, but in other contexts initial stress is ungrammatical.

that this requires extra derivational morphology to turn the adverb into a proper adjective. Moreover, the resulting adjectives can only be used attributively.

(i) Present-day Dutch

De vergadering gisteren heeft duidelijk gemaakt dat (...)

the meeting yesterday has clear made that

'The meeting yesterday has made clear that (...)'

(ii) Present-day German

die gestr-ig-e

Sammlung

the yesterday-ADJ-INFL meeting

'the meeting yesterday' 
Interestingly, the predicative and adverbial patterns are alike, as opposed to the attributive pattern.

\section{Diachronic Developments.}

In order to understand how English developed a different classification of the modifier parts-of-speech from that found in Dutch and German, the historical background of the adverbial system needs to be looked into. In Middle Dutch and Middle High German, the most common way to build adverbs from adjectives was by the inflectional ending - $e$ (schwa), which can be traced back to an isolated case form, possibly an Indo-European ablative in $-\bar{o} d$ (see Schönfeld \& Van Loey 1964:240). In the course of time, the adverbial case form eased itself away from the inflectional paradigm and became an opaque derivational morpheme. ${ }^{11}$ In Gothic, for instance, the adverbial ending at issue appears as $-\bar{o}$, as shown in 8 , which can no longer be linked with the adjectival inflection.

(8) Gothic (www.wulfila.be, John 18:20)

Ik andaugjo rodida manasedai

I openly spoke world.DAT

'I spoke openly to the world.'

The Middle Dutch and Middle High German adverbial schwa came under pressure because of the high functional load on the schwa phoneme, which appeared everywhere in inflectional paradigms after the distinct, full vowels had phonetically eroded. Its instability as an adverbial morpheme is clear from the fact that already in Middle Dutch (see Stoett 1923:76) and in Middle High German it was occasionally dropped. ${ }^{12}$

\footnotetext{
${ }^{11}$ This course of events is theoretically interesting in its own right, as it is a case of the rare process of DEGRAMMATICALIZATION, at least if we accept that inflectional morphology is more grammatical than derivational morphology. This matter will not be pursued here.

${ }^{12}$ Examples in 10 are extracted from http://www.mhdbdb.sbg.ac.at. We would like to thank Geert Stuyckens and Luk Draye for their help with the data.
} 
(9) Middle Dutch (Stoett 1923:76)

a. Recht-e opten Paeschdach right-ADV on.the easter.day

'Right on Easter Day'

b. Recht in dese selve sprake right in this self speech

'Right in this same speech'

(10) Middle High German

a. dinir rede bin ich uile fro your.GEN speech am I very glad 'I am very glad about your words.'

b. Nû ist vil edellîcher now is much graceful.cOMP 'Now it is much more graceful.'

Another way of relieving the functional load on the adverbial schwa was to use new adverbial morphology. Such a process of renewal is known to occur in other domains of morphosyntax as well (see Hopper \& Traugott 2003:122-124). One of the most prominent morphemes was -lic (currently written as -lijk) in Dutch and its German counterpart -lich. This suffix, reconstructed as ${ }^{+}-l \bar{k} k a$ - in Proto-Germanic, was the result of a grammaticalization early on in the history of the Germanic languages from a noun meaning 'body'. Originally, the suffix did not derive adverbs, but rather adjectives. In adverbial use, it was extended with a regular adverbial ending ( $-o$, later schwa). However, a reanalysis took place, so that the whole form like/lihho became an adverbializer (see Pounder 2001:304, Schönfeld \& Van Loey 1964:199, Van der Horst 2008:272). Example 11 is from Middle Dutch.

(11) Middle Dutch (MNW s.v. rechtelike)

Soo dat hi mitten werken bewijst dat hi

so that he with.the works proves that he

in god recht-elick gelooft

in god right-ADV believes

'So that he proves in his deeds that he sincerely believes in God.' 
Still, the whole system was by no means clear-cut, and it would be a gross oversimplification to say that Middle Dutch and Middle High German had a clear morphological part-of-speech distinction between adverbs and adjectives. In other words, the -lijk/-lich suffix never took off as an obligatory adverbializer like present-day English -ly. The same is true for Early-Modern English -ly (see Mustanoja 1960:314, Nevalainen 1997, Pounder 2001). In the subsequent centuries, English on the one hand, and Dutch and German on the other took radically different courses. By the nineteenth century, the English strategy to mark adverbial use with -ly became regularized. English uses the -ly suffix to mark the distinction between adjectives and adverbs in a systematic way, while Dutch and German do not.

The question is, of course, what triggered the later differences between the continental and non-continental languages. Apart from external factors (such as contact with French, stylistic preferences, standardization), internal factors can reasonably be assumed to have played a role as well (see also Pounder 2001 for an integrated approach). One of these factors is the difference in functional load on the -lijk/lich/ly suffix in the various languages. As we have argued above, -lijk/lich/ly was originally an adjectivizing suffix, rather than an adverbializer. It was mainly used to build adjectives from nouns.

English differs from Dutch and German in that it allows noun > adjective category shifts very easily, often without any morphological marking (see also Van Haeringen 1956:58-59). This means that the -lijk/lich suffix was more indispensible than the -ly suffix in its adjectivizing function. Dutch adjectival -lijk formations indeed often correspond to English zero derivations, for example, menselijk verstand versus human intelligence, vijandelijk vliegtuig versus enemy plane.

The reason for the ease with which English allows plain nouns in attributive position probably has to do with the early erosion of adjectival inflection in English. As long as adjectives inflect, "uninflectable" parts of speech are avoided in attributive position. Indeed, those syntactic contexts that trigger a zero-ending on adjectives in Dutch (namely, singular indefinite neuter NPs, see above) do allow uninflectable words, such as the adverb genoeg in 12a. Also, adverbs that end in -en can be 
used attributively, as adjectives that end in -en remain uninflected for phonetic reasons, see $12 \mathrm{~b} .^{13}$

$\begin{array}{clllll}\text { (12) a. een } & \text { groot } & \text { genoeg } & \text { deel } /{ }^{\text {? }} \text { groot } & \text { genoeg-e } & \text { delen } \\ \text { a } & \text { big } & \text { enough } & \text { part/big } & \text { enough-INFL } & \text { parts }\end{array}$

b. een open deur ${ }^{? ?}$ een toe-ë deur

an open door/a closed-INFL door

To sum up: since the Early Modern period, English has been drifting away from Dutch and German by steadily consolidating adverbial -ly. In the next section, we demonstrate that this process of divergence still continues today.

\section{New Developments.}

Derivational morphology for creating adverbs does exist in present-day Dutch and German (see, among others, Booij 2002:133, Haeseryn et al. 1997:737ff, Duden 2005:771ff). An overview is given in 13 below.

a. Dutch $^{14}$

-erwijs/-erwijze, -gewijs/-gewijze, -halve, -iter, -jes, -lijk, -lings, -s, -waarts, -weg

\footnotetext{
${ }^{13}$ The early erosion of adjectival inflection in English, as compared to Dutch and German, also meant that Early Modern English could not rely on its adjectival inflection to differentiate between adjectives and adverbs, so that there may have been a greater need to look out for other (derivational) means to mark the distinction. Still, as one anonymous reviewer of this paper rightly pointed out, the observation that some substandard varieties of English have both a high deflection rate and allow -ly to be omitted shows that this need was not necessarily urgent.

${ }^{14}$ Though historically related, -erwijs and -gewijs should be considered two different suffixes, given their different functions and the fact that they attach to different stems. For these differences as well as their variants with schwa, see Van de Velde 2005.
} 


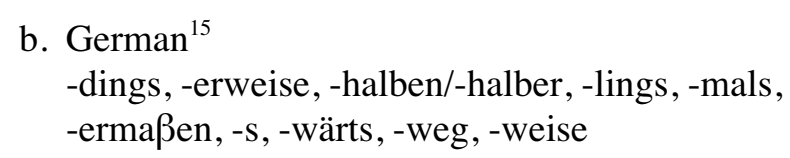

One may wonder why Dutch and German need these derivational suffixes if adjectives can be used adverbially without any morphological marking. Yet, contrary to English $-l y$, which has been consolidated, Dutch and German are either downplaying or discarding their adverbial morphology and its adverbializing function. Therefore, they can be said to be still undergoing the change towards the system proposed in table 1 .

\subsection{Loss of Productivity.}

The first indication of the erosion of Dutch and German adverbial suffixes is that throughout the centuries, they have been losing their productivity. Booij (2002:134) notes that derivation with adverbial suffixes is not very productive in present-day Dutch, and we find the same comment made for German in Duden (2005:771). Indeed, of the list of adverbial suffixes in 13 there seem to be only a few productive ones left. Two small case studies may demonstrate the loss of productivity of adverbial suffixes: adverbial-lijk/-lich and adverbial $-s$.

The suffix -lijk/-lich was used to create adverbs out of adjectives as the original adverbial ending $-e$ had eroded (see section 3 ). The suffix had a very productive period in the history of both Dutch (see, for instance, van der Horst 2008, 1265) and German (see, for instance, Schmid 2000). Dutch adverbial derivations with -lijk are abundant in the late Middle Ages, and they can still be found in the seventeenth century, but they become less frequent in the eighteenth century (for an overview, see Paardekooper 1991). In Late Modern Dutch, adverbial -lijk completely lost its productivity. Today, it is no longer in use for adverb derivation in Dutch (de Haas \& Trommelen 1993:353) ${ }^{16}$ In German, too, adverbial -lich lost its productivity (Heinle 2004, Schmid 2000:50).

\footnotetext{
${ }^{15}$ German -erweise and -weise need to be considered two different suffixes for the same reasons as Dutch -erwijs/-gewijs. Notice that English only uses -wise for deriving denominal adverbs.

${ }^{16}$ The adverbs in -lijk that we find today are remnants, often used in more or less fixed combinations, and mostly restricted to formal language (compare Paardekooper 1991:163, 167).
} 
This is also true for the adverbial suffix $-s$. This suffix has its origin in a Germanic genitive singular case ending expressing time and place (see, for example, Royen 1948:48). As it was used in so many adverbs, this genitive ending was reinterpreted as an adverbializing suffix. First indications of this are feminine nouns taking the $s$-ending, such as nachts 'at night'. Adverb formation with $-s$ was very popular in Middle High German (Wilmanns 1899:611).

The same holds for Dutch: by the sixteenth century, $-s$ was one of the dominant adverbial suffixes (van der Sijs 2002). ${ }^{17}$ It $-s$ was used to derive adverbs from various words (De Vooys 1967:257), and was also added to many existing adverbs. Middle Dutch dickwijl 'often', for instance, was turned into dikwijls (see, among others, van der Sijs 2002:173). ${ }^{18}$

However, from the seventeenth century onwards, adverb formation with $-s$ decreased (van der Sijs 2002:173). New derivations are sporadically found until the second half of the nineteenth century, but in present-day Dutch adverbial $-s$ is unproductive. In German it is hardly productive (Lohde 2006:292). Many of the old derivations have disappeared (compare Wilmanns 1899:611). Likewise, the suffix sequences -lings and -dings are no longer productive (Duden 2005:771, Haeseryn et al. 1997). ${ }^{19}$

${ }^{17}$ Royen (1948:49) notes that the process of genitive $-s$ becoming a productive adverbial suffix took place independently in both German and Dutch. This did, however, facilitate borrowing of derivations from German into Dutch.

${ }^{18}$ The adverbial ending $-s$ could also be productively attached to other derivational suffixes (see, among others, De Vooys 1967:258). This gave rise to suffix sequences such as Dutch -waarts / German -wärts (voorwaarts/vorwärts 'forward'), Dutch and German -lings (blindelings/blindlings 'blindly'), German -dings (neuerdings 'lately'), and Dutch -jes (zachtjes 'softly'). These were productive means for adverb derivation in Middle Dutch and Middle High German.

${ }^{19}$ German -wärts does have limited productivity (Lohde 2006:293; Fleischer \& Barz 1995:286), and Dutch -waarts as well, though it is restricted to the written language (Haeseryn et al. 1997:740). Dutch -jes and -weg seem to be more productive. However, there are indications that these suffixes are not adverbializers in the strict sense. Attributive and predicative use of derivations with these suffixes is not uncommon (see Hüning \& Diepeveen 2009 on -weg; see also section 4.3). Possibly, the suffixes specialize in making specific semantic contributions (see also 4.2). As for -jes, it may have a mitigating function, an 


\subsection{Suffix Specialization.}

Unlike the suffixes discussed in 4.1, German -erweise and its Dutch cognate -erwijs are still used for adverb formation. Particularly German -erweise is extremely productive (see, among others, Heinle 2004). However, this suffix is not so much an adverbializer. There are indications that this suffix is specializing in a particular function as sentence adverbial.

As illustrated in section 2, German and Dutch do not need derivational morphology on the adjective to have it function as an adverbial. Notice, however, that there is an obvious difference between the two German sentences in 14 .

a. Er spricht seltsam

he speaks strange

'He speaks strangely.'

b. Seltsam-erweise spricht in Deutschland

strange-ADV speaks in Germany

kaum jemand davon

hardly anyone thereof

'Strangely (enough), hardly anyone in Germany ever speaks about it.'

The same difference can be observed in Dutch (see 15). ${ }^{20}$

idea already raised by Te Winkel (1862:106); indeed, the suffix cannot be used with adjectives like hard ('hard'), enorm ('enormous') or zwaar ('heavy'). Further support can be found in Haeseryn et al. (1997:737), who state that jesderivations tend to have an affective or ironic meaning.

${ }^{20}$ In Dutch, addition of -erwijs is not obligatory, however. This is partly due to the fact that Dutch has yet another, more productive way of marking sentence adverbs, with genoeg, as in vreemd genoeg 'strangely enough' (see Diepeveen 2010). 


\section{(15) Present-day Dutch}

a. De werking van de schakelingen wordt the working of the circuits is

begrijpelijk uitgelegd

understandable explained

'The working of the circuits is explained understandably.'

b. Dit wordt, begrijpelijk-erwijs, uitgelegd als het this is understandable-ADV explained as the zoveelste blijk van een ongemotiveerde umpteenth evidence of a uncommitted voetballer footballer

'Understandably, this is explained as the umpteenth evidence of an uncommitted football player.'

Syntactically, the derived adverb in $14 \mathrm{~b}$ and $15 \mathrm{~b}$ has the entire sentence in its scope, which makes it - contrary to the adverbs in $14 \mathrm{a}$ and $15 \mathrm{a}-\mathrm{a}$ sentence adverbial. By means of this modifier the speaker gives a subjective comment on the main content of the sentence. Whereas the sentence modifiers receive formal marking, as shown in the b-sentences, German and Dutch manner modifiers, as in the a-sentences, remain unmarked.

Historically, -erwijs/-erweise started out as a suffix for deriving manner adverbials, that is, adverbials modifying the verb phrase (predicate-level modifiers). An early example is given in 16.

(16) Early Modern Dutch (16th century, WNT s.v. luisteren II)

Die aan een mans huys gaat luysteren

Who on a man's house goes listen

heymelyker wyse, breukt een groote boete surreptitiously is.punished.with a large fine

'Who surreptitiously eavesdrops on a man's house is punished with a large fine.' 
On the basis of corpus data, Van de Velde (2005) shows that Dutch deadjectival -erwijs derivations widened their scope from predicate modification to the entire sentence from the seventeenth century onwards. The proportion of sentence adverbials rose steadily during the Modern Dutch period, to finally dominate in the twentieth century. In German, too, the use of -erweise derivations with sentence scope increased in the nineteenth century to become central and highly productive in the twentieth century (Heinle 2004:241-242). Particularly, the use as an evaluative modifier is consolidated in present-day German (see also Diepeveen 2010). ${ }^{21}$ In English, by contrast, the suffix -ly is used for all semantic types of adverbial modification, whether on a predicative level or on a sentence level.

\subsection{Predicative/Attributive Use and Inflection.}

The third sign of the eroding functionality of Dutch and German adverbial suffixes is the fact that the derivations no longer exclusively function as adverbial modifiers. They are used both predicatively and as prenominal attributes. In the latter case, they are inflected. ${ }^{22}$ The attributive use of denominal German weise-and Dutch gewijs-derivations is well known and is illustrated in examples 17-18.

\section{(17) Present-day German (DWDS)}

in der ...schritt-weis-en Radikalisierung

in the ...step-ADV-INFL radicalization

'in the ... gradual radicalization'

(18) Present-day Dutch (Royen 1948:199)

een trap-sgewijze overgang

a step-ADV transition

'a gradual transition'

${ }^{21}$ Note that participles are also possible as base words for -erweiselerwijs derivations (for instance, Dutch vergelijkenderwijs 'comparatively'; see Van de Velde 2005).

${ }^{22}$ The possibility of inflection is generally used as a criterion for distinguishing adjectives from adverbs. 
Attributive use of weise-derivations is said to be a fairly new phenomenon, with rising frequency (Fleischer \& Barz 1995:288, Heinle 2004, Duden 2005). According to Heinle (2004), the origin of attributive use of weise-derivations dates back to the sixteenth century. For Dutch, there are examples from the seventeenth century.

(19) Early Modern Dutch (17th century, WNT s.v. klos)

een klos-gewijs penne-ken

a reel-ADV pin-DIM

'a small reel-like pin'

Other derivations with adverbial suffixes are used predicatively and attributively, too, as shown in 20. Fleischer \& Barz (1995:263) mention "eine gewisse Tendenz" for adverbial lich-derivations to be used attributively. Schmid (2000:49) situates attributive use of adverbial lichderivations in the New High German period.

(20) Present-day German (Schmid 2000:49)

fälsch-lich-e Zuordnung

false-ADV-INFL classification

'incorrect classification'

Likewise, Royen (1954:138) notices that Dutch adverbial lijk-formations can be used attributively, particularly attributive waarlijk, as shown in 21.

(21) Present-day Dutch (Royen 1954:138)

een waar-lijk-e wereld-beschouwing

a real-ADV-INFL world-view

'a real world view'

Further, there are examples of attributive use of German formations with -ling:

(22) Present-day German (Henzen 1965:248)

der jäh-ling-e Abschied

the sudden-ADV-INFL farewell

'the sudden farewell' 
According to Royen (1954:138), Dutch adverbs in $-s$ are adjectivized to a large extent. In his work, we find scattered attributive examples for -lings and -waarts. Royen (1948:55) further gives examples for attributive use of a formation with -halve. ${ }^{23}$ See 23 and 24 for more examples.

(23) Present-day Dutch (Royen 1954:139)

het zijde-lings verminken

the side-ADV mutilation

'the sideward mutilation'

(24) Present-day Dutch (38MWC)

a. een achter-waarts-e kopstoot

a back-ADV-INFL header

'a backward header' ${ }^{24}$

b. De ambt-shalve pensionering vanaf 60 jaar

the office-ADV retirement from 60 year

'the retirement by virtue of one's office by the age of 60 '

Attributive use of jes-derivations does not occur, according to Royen (1948:55). Yet, various more recent sources, such as Haeseryn et al. 1997:737, show that it does, as in 25. Inflection of jes-derivations does not seem to be possible for phonological reasons.

(25) Present-day Dutch (Haeseryn et al. 1997:737)

zacht-jes gelach

quiet-ADV laughter

'quiet laughter'

A Google search reveals that attributive use is also attested for derivations with -weg and -erwijs, as shown in 26 . These examples may not be acceptable to all native speakers, but particularly those with -weg are too frequent to be dismissed as nonce formations (see also Hüning \&

\footnotetext{
${ }^{23}$ In German such attributive forms may be blocked if there are corresponding derived adjectives, for example, rückwärtig for rückwärts 'backwards'.

24 As the English translation shows, attributive use of ward-formations is possible there as well.
} 
Diepeveen 2009 on -weg). They may indicate that many language users do not feel that words derived with adverbial suffixes are by definition adverbs anymore.

(26) Present-day Dutch

a. een grof-weg-ge onderverdeling

a rough-ADV-INFL subdivision

'a rough subdivision'

b. een redelijk-erwijs pakket

a reasonable-ADV set

van $80 \%$ of $90 \%$ dienst-uren

of $80 \%$ or $90 \%$ service-hours

'a reasonable work load of 80 or $90 \%$ service duty'

\section{Conclusion.}

At the end of the Middle English, Middle Dutch, and Middle High German period, all three languages had an inconsistent system to distinguish between adjectives and adverbs. In the course of the following centuries, English systematized the distinction with the aid of the adverbializer -ly. This development of sharpening the part-of-speech boundaries is remarkable, considering the ubiquitous deflection tendency in the language (see Van Haeringen 1956:39). In contrast, Dutch and German gave up on the distinction.

What has often been overlooked, however, is that the latter languages display an ongoing tendency to draw another distinction among modifiers. Instead of distinguishing adjectives and adverbs, Dutch and German distinguish attributive modifiers on the one hand and adverbial and predicative modifiers on the other. In this system, there is only a marginal role for adverbial morphology. Instead, adjective inflection has gained importance as the new system is built around it. The fact that derivations with adverbial suffixes are inflected prenominally constitutes further evidence for the generalization of adjectival inflection on attributive modifiers.

German and Dutch, thus, have come to use inflection as a means to distinguish parts of speech. Though this may have theoretical consequences that go beyond the scope of this paper, in that the distinction 
between inflection and derivation is at best fuzzy and changes need not proceed unidirectionally from derivation to inflection, this development is not unprecedented. The Middle High German and Dutch derivational adverbial schwa also came from an inflectional form, showing how language users exploit extant morphology to make sense of the grammar they inherit from previous generations.

\section{REFERENCES}

Booij, Geert. 2002. The morphology of Dutch. Oxford: Oxford University Press. Brinton, Laurel J., \& Elisabeth Closs Traugott. 2005. Lexicalization and language change. Cambridge: Cambridge University Press.

Diepeveen, Janneke. 2010. Interestingly, interessanterweise, interessant genoeg: De contrastieve methode als blikverruimer bij de studie van Nederlandse evaluatieve bijwoorden. Berlin: University Manuscript.

Duden: Duden. Die Grammatik 2005. 7th edn., ed. by , Kathrin Kunkel-Razum \& Matthias Wermke. Mannheim: Dudenverlag.

Fleischer, Wolfgang, \& Irmhild Barz. 1995. Wortbildung der deutschen Gegenwartssprache. 2nd edn. Tübingen: Max Niemeyer.

Haas, Wim de, \& Mieke Trommelen. 1993. Morfologisch handboek van het Nederlands. Een overzicht van de woordvorming. 's-Gravenhage: SDU.

Haeringen, Coenraad Bernardus van. 1956. Nederlands tussen Duits en Engels. The Hague: Servire.

Haeseryn, Walter J., Kirsten Romijn, Guido Geerts, Jaap de Rooij, \& Maarten C. van den Toorn. 1997. Algemene Nederlandse spraakkunst. 2nd edn. Groningen/Deurne: Martinus Nijhoff/Wolters Plantyn.

Heinle, Eva-Maria. 2004. Diachronische Wortbildung unter syntaktischem Aspekt. Das Adverb. Heidelberg: Universitätsverlag Winter.

Henzen, Walter. 1965. Deutsche Wortbildung. 3rd edn. Tübingen: Max Niemeyer Verlag.

Hopper, Paul J., \& Elizabeth C. Traugott. 2003. Grammaticalization. 2nd edn. Cambridge: Cambridge University Press.

Horst, Joop van der. 2008. Geschiedenis van de Nederlandse syntaxis. Leuven: Leuven University Press.

Hüning, Matthias, \& Janneke Diepeveen. 2009. Simpelweg een suffix? Over bijwoordvorming met -weg. Fons verborum. Feestbundel voor prof. dr. A. M. F. J. (Fons) Moerdijk, aangeboden door vrienden en collega's bij zijn afscheid van het Instituut voor Nederlandse Lexicologie, ed. by Egbert Beijk, Lut Colman, Marianne Göbel, Frans Heyvaert, Tanneke Schoonheim, Rob 
Tempelaars, \& Vivien Waszink, 369-380. Leiden: Instituut voor Nederlandse Lexicologie.

König, Ekkehard, \& Volker Gast. 2007. Understanding English-German contrasts. Berlin: Schmidt.

Kruyt, Johanna Geertruida, \& M. W. F. Dutilh. 1997. A 38 million words Dutch text corpus and its users. Lexikos 7. 229-244.

Lohde, Michael. 2006. Wortbildung des modernen Deutschen. Ein Lehr- und Übungsbuch. Tübingen: Narr.

MNW: Middelnederlandsch Woordenboek. 1998. 's-Gravenhage: Sdu. CD-rom version of: Eelco Verwijs and Jacob Verdam. 1885-1952.

Middelnederlandsch Woordenboek. 's-Gravenhage: Martinus Nijhoff.

Mustanoja, Tauno F. 1960. A Middle English syntax. 1: Parts of speech. Helsinki: Société Néophilologique.

Nevalainen, Terttu. 1997. The processes of adverb derivation in Late Middle and Early Modern English. Grammaticalization at work. Studies of long term developments in English, ed. by Matti Rissanen, 145-189. Berlin: Mouton de Gruyter.

Paardekooper, Piet C. 1991. Hij weende bitterlijk. Een stukje bijwoordmorfologie. Gramma 15. 147-171.

Paraschkewoff, Boris. 1974. Zur Entwicklung des qualitativen Adverbs im Deutschen. Deutsch als Fremdsprache 11. 288-291.

Pounder, Amanda. 2001. Adverb-marking in German and English. System and standardization. Diachronica 18. 301-358.

Royen, Gerlach P. 1948. Buigingsverschijnselen in het Nederlands. Deel II. Amsterdam: Noord-Hollandsche Uitgevers Maatschappij.

Royen, Gerlach P. 1954. Buigingsverschijnselen in het Nederlands. Deel IV (Slotstuk). Amsterdam: Noord-Hollandsche Uitg. Maatschappij.

Schmid, Hans Ulrich. 2000. baldlîhho sprehhan > baldlîhhiu wort. Adjektive auf -lîh in abgeleiteten Nominalgruppen im Althochdeutschen. Zur Geschichte der Nominalgruppe im älteren Deutsch. Festschrift für Paul Valentin: Akten des Pariser Kolloquiums März 1999, ed. by Yvon Desportes, 41-51. Heidelberg: Winter.

Schönfeld, Moritz, \& Adolphe van Loey. 1964. Schönfelds historische grammatica van het Nederlands. Zutphen: Thieme.

Sijs, Nicoline van der. 2002. Chronologisch Woordenboek. De ouderdom en herkomst van onze woorden en betekenissen. Amsterdam: Uitgeverij L. J. Veen.

Stassen, Leon. 2008. Predicative adjectives. The world atlas of language structures online, ed. by Martin Haspelmath, Matthew S. Dryer, David Gil, \& Bernard Comrie. Munich: Max Planck Digital Library, chapter 118 (http://wals.info/feature/118). Date accessed: 29 September 2010. 
Stoett, Frederik August. 1923. Middelnederlandsche Spraakkunst. Syntaxis. 'sGravenhage: Martinus Nijhoff.

Te Winkel, Lammert A. 1862. Over de verkleinwoorden. De Taalgids 4. 81116.

Velde, Freek Van de. 2005. Exaptatie en subjectificatie in de Nederlandse adverbiale morfologie. Handelingen der Koninklijke Zuid-Nederlandse Maatschappij voor Taal- en Letterkunde en Geschiedenis 58. 105-124.

Velde, Freek Van de. 2009. De nominale constituent. Structuur en geschiedenis. Leuven: Leuven University Press.

Vooys, Cornelis G. N. de. 1967. Nederlandse spraakkunst. 7th edn. Groningen: Wolters.

Weerman, Fred P. 2003. Een mooie verhaal. Veranderingen in uitgangen. Waar gaat het Nederlands naartoe? Panorama van een taal, ed. by Jan Stroop, 249-260. Amsterdam: Bert Bakker.

Weerman, Fred P. 2005. Adverbia als adjectiva. A.D. 2005. Taalkundige artikelen voor Ad Welschen, ed. by Els Elffers \& Fred P. Weerman, BLA. Amsterdam: Faculteit der Geesteswetenschappen Uva.

Weerman, Fred P., Jannetje Bisschops, \& Laura Punt. 2006. L1 and L2 acquisition of Dutch adjectival inflection. ACLC Working Papers 1. 5-36.

Wilmanns, Wilhelm. 1899. Deutsche Grammatik. Gotisch, Alt-, Mittel- und Neuhochdeutsch. Strassburg: Trübner.

WNT: Woordenboek der Nederlandsche Taal. 2003. 's-Gravenhage: Sdu. Cdromversion of Matthias de Vries and Lammert A. Te Winkel. 1882-1998. Woordenboek der Nederlandsche taal. 's-Gravenhage: Martinus Nijhoff.

Janneke Diepeveen

Institut für Deutsche und Niederländische Philologie

Freie Universität Berlin

Habelschwerdter Allee 45

D-14195 Berlin

Germany

[j.diepeveen@fu-berlin.de]

Freek Van de Velde

University of Leuven

Blijde Inkomststraat 21, P.O. Box 3308

B-3000 Leuven

Belgium

[freek.vandevelde@arts.kuleuven.be] 